НАУКОВИЙ ВІСНИК

Scientific messenger of Lviv National University

.

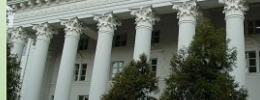

1.

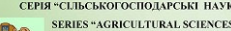

Том 22 № 93 2020
Науковий вісник Дьвівського національного університету ветеринарної медицини та біотехнологій імені С.3. Гжицького. Серія: Сільськогосподарські науки

Scientific Messenger of Lviv National University of Veterinary Medicine and Biotechnologies. Series: Agricultural sciences https://nvlvet.com.ua/index.php/agriculture

UDC 639.3:639.311.003.13

\title{
Conditions for carp growing in feeding ponds of the Yaniv fishery
}

\author{
P. Ja. Pukalo ${ }^{1}$, L. Ja. Bozhyk ${ }^{1}$, O. Ja. Dumych², S. M. Tonkonozhenko \\ ${ }^{1}$ Stepan Gzhytskyi National University of Veterinary Medicine and Biotechnologies Lviv, Ukraine \\ ${ }^{2}$ Ivan Franko National University of Lviv, Lviv, Ukraine
}

Article info

Received 17.08.2020

Received in revised form 21.09 .2020

Accepted 22.09.2020

Stepan Gzhytskyi National University of Veterinary Medicine and Biotechnologies Lviv, Pekarska Str., 50, Lviv, 79010, Ukraine. Tel.: +38-097-234-84-19 E-mail: hoarding@ukr.net

Ivan Franko National University of Lviv, Hrushevsky Str., 4 . Lviv, 79005, Ukraine.

E-mail:oks_um@ukr.net

Pukalo, P. Ja., Bozhyk, L. Ja., Dumych, O. Ja., \& Tonkonozhenko, S. M. (2020). Conditions for carp growing in feeding ponds of the Yaniv fishery. Scientific Messenger of Lviv National University of Veterinary Medicine and Biotechnologies. Series: Agricultural sciences, 22(93), 3539. doi: 10.32718/nvlvet-a9306

The article presents the results of research on the ecological conditions of carp farming in feeding ponds, which were carried out on the basis of the fishery "Yaniv", which is part of PrJSC "Lviv Regional Fish Production Plant". The research was carried out during the vegetation period of 2019 in accordance with the methods adopted in hydrobiology and fish farming. The hydrochemical state of the studied reservoirs and their biotic component, in particular zooplankton and zoobenthos, were analyzed. The results of studies of water quality of feeding ponds of the fishery "Yaniv" show that the hydrochemical parameters during the study period in the vast majority were within the maximum permissible concentrations set for fish farms; sometimes were registrated some indicators which slightly exceeded the normative limits, in particular permanganate oxidation, nitrites, phosphates, chlorides. The study of the natural forage base by zooplankton and zoobenthos revealed that the values of development of the studied aquatic organisms corresponded to the limits of development, which are characteristic of the ponds of the studied type of the ForestSteppe zone. The values of zooplankton biomass in the experimental ponds were in the range of 5.3$12.5 \mathrm{~g} / \mathrm{m}^{3}$. The dynamics of zooplankton development in feeding ponds shows its maximum development in early summer and some decrease in the second half of the vegetation season. In general, the basis of its biomass was consisted of Cladocera (Daphnia magna Straus, Bosmina longirostris, Daphnia cucullata Sars, Ceriodaphnia quadrangula OF Müller, Moina rectirostris Leydig), representatives of Copepoda (Thermocyclops crassus Fischer), Calanoida (Diaptomus castor Jurine, Eudiaptomus coeruleus Fischer) and Rotatoria (Brachionus diversicornis Daday, B.calyciflorus Pallas, Filinia longiseta Ehrb., Keratella cochlearis Gosse). Cladocera and Copepoda made the largest contribution to biomass, while Rotatoria had almost twice less share of total biomass. Indicators of zoobenthos biomass in ponds were in the range of $4.9-6.8 \mathrm{~g} / \mathrm{m}^{2}$. The maximum development of benthic organisms was observed in late spring. The basis of biomass of zoobenthos was mainly consisted of insect larvae and oligochaeta. fish.

Key words: temperature, hydrochemical regime, hydrobiological regime, natural forage base of ponds,

\section{Умови вирощування коропа у нагульних ставах рибного господарства "Янів"}

П. Я. Пукало ${ }^{1}$ Л. Я. Божик ${ }^{1}$, О. Я. Думич², С. М. Тонконоженко ${ }^{1}$

${ }^{1}$ Львівський національний університет ветеринарної медицини та біотехнологій імені С. 3. Гљицького, м. Львів, Україна

${ }^{2}$ Львівський національний університет імені І. Франка, м. Львів, Украӥна

У статті наведено результати досліджень екологічних умов вирощування коропа у нагульних ставах, які проводили на базі рибного господарства “Янів”, щчо входить до складу ПрАТ “Львівський обласний виробничий рибний комбінат”. Дослідження здійснювали протягом вегетаційного періоду 2019 р. згідно з прийнятими у гідробіології та рибництві методиками. Проаналізова- 
ні гідрохімічний стан досліджуваних водойм та ӥхня біотична складова, зокрема зоопланктон та зообентос. Результати досліджень якості води нагульних ставів рибного господарства “Янів" показують, шуо гідрохімічні показники протягом досліджуваного періоду в переважній більшості перебували у межах гранично допустимих концентрацій, встановлених для рибницьких господарств; інколи реєстрували незначне перевищення нормативних меж деяких показників, зокрема перманганатної окислюваності, нітритів, фосфатів, хлоридів. У результаті вивчення природної кормової бази за зоопланктоном та зообентосом встановлено, ияо показники розвитку досліджуваних гідробіонтів відповідають межам розвитку, які є характерними для ставів досліджуваного типу Лісостепової зони. Значення біомаси зоопланктону у дослідних ставах перебували в межах 5,3-12,5 г/м ${ }^{3}$. Динаміка розвитку зоопланктону у нагульних ставах показує його максимальний розвиток на початку літа та деяке зниження у другій половині вегетаційного періоду. Загалом основу його біомаси складали гіллястовусі раки (Daphnia magna Straus, Bosmina longirostris O. F. Müller, Daphnia cucullata Sars, Ceriodaphnia quadrangula O. F. Müller, Moina rectirostris Leydig) ma веслоногi paки (npeдcmaвники Calanoida - Diaptomus castor Jurine, Eudiaptomus coeruleus Fischer, ma Copepoda - Thermocyclops crassus Fischer) $i$ npedcmaвники круглих червів - коловертки (Brachionus diversicornis Daday, B. calyciflorus Pallas, Filinia longiseta Ehrb., Keratella cochlearis Gosse). Найбільший вклад у біомасу вносили Cladocera і Сорерода, майже вдвічі менша частка в загальній біомасі - у представників Rotatoria. Показники біомаси зообентосу у ставах були в межах 4,9-6,8 г/м². Максимальний розвиток бентосних організмів спостерігався наприкінці весни. Основу біомаси зообентосу складали переважно личинки комах і олігохети.

Ключові слова: температура, гідрохімічний режим, гідробіологічний режим, природна кормова база ставів, риба.

\section{Вступ}

Риба та рибні продукти мають важливе значення для забезпечення нормального розвитку і життєдіяльності людського організму, оскільки вони є джерелом необхідних вітамінів, макро- та мікроелементів, повноцінних білків тваринного походження (Pukalo \& Shekk, 2018).

Усі життєві процеси, що відбуваються в організмі риб, тісно пов'язані із зовнішнім середовищем і перебувають під його безпосереднім впливом (Grynevych et al., 2018; Rudenko et al., 2019; Vodianitskyi et al., 2020). Важливе місце у вирощуванні риб належить абіотичним та біотичним умовам середовища вирощування. Серед основних абіотичних чинників довкілля, які обумовлюють ефективність вирощування риби, є температурний, кисневий, хімічний режими ставів тощо. Серед біотичних чинників - природна кормова база водойми.

За умов рибницьких ставів особливо зростає роль водного середовища як чинника, який регулює функціонування гідробіонтів, оскільки у водну товщу вносять різні види добрив, штучні корми та застосовують високу густоту посадки риби.

Алгоритм функціонування водних екосистем передбачає постійну взаємодію біотичної й абіотичної складової. Гідробіонти як компонент водних екосистем у процесі своєї життєдіяльності змінюють середовище існування, впливаючи на його хімічний склад характеристики. Вода, зазнавши якісних змін, своєю чергою визначає темпи росту, розвитку і відтворення, виживання, видовий склад гідробіонтів, що забезпечує функціонування водної екосистеми як єдиного механізму (Grygorenko et al., 2016).

Гідрохімічний режим відіграє важливу роль у життєдіяльності гідробіонтів і $є$ одним із головних чинників, що впливають на розвиток природної кормової бази та рибопродуктивність ставів. Його формування залежить від кліматичних i грунтово-геологічних умов, джерела водопостачання, замуленості, густоти посадки риби, засобів інтенсифікації тощо (Grygorenko et al., 2016).

Серед різноманітних чинників зовнішнього середовища найважливіше значення мають фізичні та гідрохімічні показники, зокрема температурний, газовий і сольовий режими (Grygorenko et al., 2019).
Хімічний склад води постійно зазнає змін - на нього впливають води джерел водопостачання, опади, стічні води, перемішування води 3 різних глибин, атмосферні та річкові води тощо. Температурний, гідрохімічний та гідробіологічний режими рибних ставів значною мірою впливають на умови вирощування, ріст та виживання коропа (Grishyn et al., 2015; Grygorenko et al., 2019).

Не менш важливим чинником середовища, який впливає на вирощування риби, є розвиток природної кормової бази у ставах, яка за вмістом поживних речовин і амінокислотним складом значно перевищує харчову цінність штучних кормів. Основними кормовими організмами для коропових риб у рибницьких ставах є фіто-, зоопланктон та зообентос. До того ж стави вважаються більш продуктивними, якщо у складі фітопланктону переважають зелені (хлорококові) водорості, зоопланктону - гіллястовусі та веслоногі ракоподібні, а зообентосу - личинки хірономід (Grishyn et al., 2015).

Мета $і$ завдання дослідження - дослідити гідрохімічні умови та розвиток природної кормової бази нагульних ставів рибного господарства “Янів” (ПрАТ “Львівський обласний виробничий рибний комбінат”).

\section{Матеріал і методи досліджень}

Дослідження проводили упродовж вегетаційного періоду 2019 р. на базі рибного господарства “Янів", що входить до складу ПрАТ “Львівський обласний виробничий рибний комбінат”.

Об'єктом досліджень були гідрохімічні показники, зоопланктон, зообентос нагульних ставів господарства "Янів".

Контроль за якістю води у ставах проводили в лабораторії ПрАТ “Львівський обласний виробничий рибний комбінат”.

Гідрохімічні та гідробіологічні (зоопланктон та зообентос) дослідження здійснювали згідно з загальноприйнятими методиками (Alekin et al., 1973; Romanenko, 2006; Krazhan \& Hyzhnjak, 2014). Проби ззазвичай відбирали у першій половині дня.

Перший гідрохімічний аналіз води у ставах здійснювали після набору води 3 джерел водопостачання. Під час вегетаційного періоду лабораторний контроль 
води проводився щодекадно. Під час скиду води зі ставів у річку лабораторією контролювали ії якість, у тому числі за повного об'єму, тобто на початку скиду, спуску води в річку на 50 \% і на 80 \%. Отримані значення порівнювали з чинними рибницькими нормативами (Voda rybohospodarskykh pidpryiemstv, 2006).

\section{Результати та їх обговорення}

Протягом періоду дослідження температура води у дослідних ставах господарства коливалась в межах $21-24{ }^{\circ} \mathrm{C}$.

\section{Таблиця 1}

Гідрохімічні показники нагульних ставів рибного господарства “Янів”

\begin{tabular}{|c|c|c|c|c|}
\hline Показники & $\begin{array}{c}\text { COY - 05.01.-37- } \\
385: 2006 \\
\end{array}$ & Травень & Червень & Липень \\
\hline Водневий показник (pH) & $6,5-8,5$ & 7,6 & 6,2 & 6,4 \\
\hline Розчинений у воді кисень $\mathrm{O}_{2}, \mathrm{мг} /$ дм $^{3}$ & $6-8$ & 5,2 & 5,6 & 4,8 \\
\hline $\mathrm{CO}_{2}, \mathrm{мг} /$ дм$^{3}$ & до 25 & 15,4 & 16,1 & 18,2 \\
\hline Окислюваність перманганатна, мг О/ дм³ & до 15 & 14,1 & 14,4 & 14,5 \\
\hline Лужність, мг-екв./дм ${ }^{3}$ & $1,8-3,5$ & 2,7 & 2,5 & 2,9 \\
\hline Амоній-іони $\mathrm{NH}_{4}{ }^{+}$, мг $\mathrm{N} /$ дм$^{3}$ & до 1,0 & 0,38 & 0,40 & 0,43 \\
\hline Нітрит-іони $\mathrm{NO}_{2-}$, мг $\mathrm{N} /$ дм$^{3}$ & до 0,1 & 0,12 & 0,34 & 0,14 \\
\hline Нітрат-іони $\mathrm{NO}_{3-}$, мг $\mathrm{N} /$ дм$^{3}$ & до 2,0 & 0,68 & 0,80 & 1,06 \\
\hline Мінеральний фосфор $\mathrm{PO}_{4}^{3-}$, мг $\mathrm{P} /$ дм$^{3}$ & до 0,5 & 0,22 & 0,86 & 0,78 \\
\hline Залізо загальне, мг Fe/ дм³ & до 1,0 & 0,30 & 0,64 & 0,68 \\
\hline Твердість загальна, мг-екв/дм³ & $2-6$ & 1,4 & 2,8 & 3,2 \\
\hline Кальцій $\mathrm{Ca}^{2+}, \mathrm{мг} /$ дм$^{3}$ & $40-60$ & 48,9 & 51,7 & 27,0 \\
\hline Хлорили, $\mathrm{Cl}^{-}, \mathrm{мг} /$ дм $^{3}$ & $25-40$ & 41,12 & 60,26 & 61,02 \\
\hline Магній, $\mathrm{Mg}^{2+}, \mathrm{мг} /$ дм $^{3}$ & до 30 & 5,47 & 7,8 & 5,6 \\
\hline Сульфати $\mathrm{SO}_{4}^{2-}$, мг/дм ${ }^{3}$ & до 1000 & 104,2 & 96,7 & 98,4 \\
\hline Загальна мінералізація, мг/дм ${ }^{3}$ & $300-1000$ & 209,1 & 224,0 & 264,1 \\
\hline
\end{tabular}

Оптимальними значеннями рН ставової води для вирощування коропа $є$ нейтральні або слаболужні. Значення $\mathrm{pH}$ у дослідних ставах господарства „Янів” коливалися в межах 7,6-6,2, що повністю відповідало нормативам.

Кількість біогенних речовин у воді перебувала в межах норми або дещо іiі перевищувала. Зокрема, в межах гранично допустимих концентрацій був уміст амонійного азоту, який складав 0,38-0,43 мг N/дм ${ }^{3}$ i нітратів, значення яких коливалися в межах 0,68 1,06 мг N/дм ${ }^{3}$, проте нітрити незначно перевищували гранично допустимі концентрації, їхній вміст складав 0,12-0,34 мг N/дм³. Вміст Заліза загального перебував у межах норми і складав 0,30-0,68 мг Fe/дм². Показники Фосфору були дещо підвищені влітку та навесні та становили відповідно 0,22-0,86 мг Р/л.

Щодо показника вмісту органічного речовини у воді - перманганатної окислюваності, то виявляли іiі незначне зростання у весняні і літні місяці, що зумовлено нагромадженням продуктів життєдіяльності риби, залишку комбікорму, решток тваринного і рослинного походження. Перманганатна окислюваність води вказує на ступінь іiі органічного забруднення, проте в даному випадку іiі вміст повністю задовольняє потреби коропових господарств.

Загальна твердість зумовлена сумарною концентрацією іонів Кальцію та Магнію. Вміст цих катіонів протягом періоду досліджень складав 27,0-51,7 мг
Кисневий режим згідно з середніми значеннями розчиненого у воді кисню перебував у межах норми і становив 4,8-5,6 мг/дм³ могам до коропових господарств. У ставах не виявляли накопичення вільного двоокису вуглецю, концентрація якого була значно нижчою за нормативні величини (табл. 1).

Лужність води дослідних ставів коливалася в незначних межах $-2,5-2,9$ мг-екв/дм³ .
$\mathrm{Ca} /$ дм$^{3}$ i 5,47-7,8 мг Mg/дм ${ }^{3}$ Ці елементи, які визначають твердість води, зумовлювали підвищення величини цього показника від 1,4 до 3,2 мг-екв/л. За кількістю розчинених мінеральних речовин вода відповідає твердим природним водам. Проте твердість іiі помірна. Мінералізація води становила 209,1-

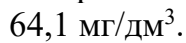

Відомо, що сульфат-іони належать до найпоширеніших іонів і завжди присутні в помірній кількості у всіх поверхневих водах, вміст хлорид-іонів, які $\epsilon$ неодмінною складовою природних вод, коливається в широких межах (Romanenko, 2006). У дослідних ставах вміст цих іонів змінювався в широких межах, зокрема концентрація хлоридів перевищувала нормативні значення і коливалася в межах від 41,12 (травень) до 61,02 (липень) мг/л.

Загалом дослідженням динаміки газового режиму, біогенних елементів та органічних речовин у воді ставів риб господарства “Янів" протягом періоду вирощування риб встановлено, що всі показники змінювалися у незначних межах.

Природну кормову базу рибогосподарських водойм формують різні угруповання планктону, бентосу, нейстону, перифітону, які включають бактеріальне населення, водорості, безхребетних, вищі водяні рослини та продукти їхнього розпаду. Природні корми мають усі необхідні для живлення риб поживні речовини: білки, жири, вуглеводи, мінеральні речовини, 
мікроелементи, вітаміни тощо. Забезпечення риб природною їжею впливає на їхній ріст протягом вегетаційного періоду, ступінь засвоєння штучних кормів $\mathrm{i}$, що особливо важливо, на рівень виживання цьоголіток та їх масу (Krazhan \& Hyzhnjak, 2014).

Показники біомаси зоопланктону в дослідних ставах змінювалися від 5,3 до 12,5 г/ $\mathrm{m}^{3}$, що відповідає межам, які є характерними для зоопланктону нагульних ставів Лісостепу (Krazhan \& Hyzhnjak, 2014).

Максимальний розвиток зоопланктонних організмів спостерігався на початку літа. У другій половині вегетаційного періоду кількість зоопланктону дещо знижувалася. Основу його біомаси складали гіллястовусі та веслоногі ракоподібні, коловертки (табл. 2).

\section{Таблиця 2}

Біомаса зоопланктону дослідних ставів рибного господарства “Янів” (г/м³)

\begin{tabular}{|c|c|c|c|}
\hline Група зоопланктону & Травень & Червень & Липень \\
\hline Rotatoria & $2,5 \pm 0,03$ & $2,4 \pm 0,04$ & $1,2 \pm 0,06$ \\
\hline Cladocera & $5,6 \pm 0,12$ & $4,6 \pm 0,14$ & $2,2 \pm 0,03$ \\
\hline Copepoda & $4,4 \pm 0,09$ & $4,8 \pm 0,11$ & $1,9 \pm 0,02$ \\
\hline Загальна біомаса & $12,5 \pm 0,24$ & $11,8 \pm 0,29$ & $5,3 \pm 0,11$ \\
\hline
\end{tabular}

Основу біомаси серед гіллястовусих раків складали Daphnia magna Straus, Bosmina longirostris O. F. Müller, Daphnia cucullata Sars, Ceriodaphnia quadrangula O. F. Müller, Moina rectirostris Leydig. Частка коловерток у біомасі зоопланктонних угруповань була невеликою. Хоч кількісно коловертки досягали високих значень, зокрема Brachionus diversicornis Daday, B.calyciflorus Pallas, Filinia longiseta Ehrb., Keratella cochlearis Gosse, проте через невелику індивідуальну вагу вони істотно не впливали на загальну величину біомаси зоопланктону протягом періоду досліджень. Будучи мирними формами, коловертки є кормом для хижих форм зоопланктону i, таким чином, позитивно впливають на формування природної кормової бази дослідного нагульного ставу.

Таблиця 3

Біомаса зообентосу дослідних ставів рибного господарства “Янів” (г/м²)

\begin{tabular}{lccc}
\hline \multicolumn{1}{r}{ Група зообентосу } & Травень & Червень & Липень \\
\hline Молюски & $0,8 \pm 0,02$ & $0,6 \pm 0,02$ & $0,4 \pm 0,03$ \\
Мізиди & $1,4 \pm 0,03$ & $1,2 \pm 0,11$ & $1,0 \pm 0,02$ \\
Личинки комах & $2,8 \pm 0,12$ & $2,6 \pm 0,14$ & $2,3 \pm 0,04$ \\
Олігохети & $1,8 \pm 0,02$ & $1,5 \pm 0,05$ & $1,2 \pm 0,03$ \\
Загальна біомаса & $6,8 \pm 0,19$ & $5,9 \pm 0,32$ & $4,9 \pm 0,12$ \\
\hline
\end{tabular}

\section{Висновки}

Провівши дослідження нагульних ставів рибного господарства “Янів", встановили, що гідрохімічні показники та розвиток природної кормової бази був задовільним. Усі досліджувані показники коливались у нормативних межах протягом сезону і тільки інколи дещо перевищували гранично допустимі концентрації хімічних речовин у воді.

Температура води у ставах на момент проведення досліджень коливалась в межах $21,0-24,0{ }^{\circ} \mathrm{C}$ i була сприятливою для вирощування риби.

Величина водневого показника $(\mathrm{pH})$ була на рівні 6,2-7,6, вміст розчиненого у воді кисню перебував у межах норми і становив 4,8-5,6 мг/дм². У воді дослідних ставів був присутній амонійний азот - 0,380,43 мг $\mathrm{N} /$ дм $^{3}$. Нітрити дещо перевищували гранично
Частка веслоногих раків у загальній біомасі була дещо меншою, ніж гіллястовусих раків. Переважно у весняний період біомасу формували наупліальні стадіï та представники Calanoida - Diaptomus castor Jurine, Eudiaptomus coeruleus Fischer, у літній - копеподитні стадії та зрілі форми Thermocyclops crassus Fischer.

При дослідженнях біомаси зообентосу в експериментальних ставах було встановлено, що ії значення перебувало в межах 4,9-6,8 г/м². Максимальний розвиток бентосних організмів спостерігався наприкінці весни. У другій половині вегетаційного періоду кількість зообентосу різко знижувалася через виїдання його мальками коропа. Основу біомаси зообентосу складали переважно личинки комах і малощетинкові черви (табл. 3). допустимі концентрації і перебували в межах 0,12 0,34 мг N/ м³ , однак нітрати не перевищували нормативних значень. Виявляли незначне підвищення перманганатної окислюваності води у весняні та літні місяці. Лужність води дослідних ставів коливалася в незначних межах - 2,5-2,9 мг-екв/дм³ ${ }^{3}$ Вміст заліза загального був у межах норми і складав 0,300,68 мг $\mathrm{Fe} /$ дм $^{3}$. Показники фосфору були дещо підвищені влітку і навесні та становили відповідно 0,220,86 мг Р/л.

Показники біомаси зоопланктону в дослідних

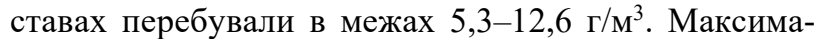
льний розвиток зоопланктонних організмів спостерігався на початку літа. У другій половині вегетаційного періоду кількість зоопланктону дещо знижувалася. Основу його біомаси складали гіллястовусі та веслоногі ракоподібні, коловертки. 
Показники біомаси зообентосу у ставах перебували

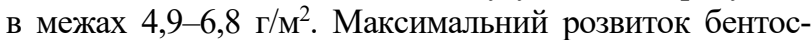
них організмів спостерігався наприкінці весни. Основу біомаси зообентосу складали переважно личинки комах і малощетинкові черви.

Перспективи подальших досліджень. Подальшим перспективним напрямом досліджень є вивчення впливу гідрохімічного режиму та природної кормової бази на продуктивність нагульних ставів при вирощуванні коропа у полікультурі з рослиноїдними рибами при використанні штучних кормів 3 метою отримання максимального приросту рибної продукції в умовах Прикарпаття.

\section{References}

Alekin, O. A., Semenov, A. F., \& Skopintsev, V. A. (1973). Rukovodstvo po khimicheskomu analizu vod sushi [Land-based Chemical Analysis Guide]. Lenihnhrad: Hidrometeoyzdat (in Russian).

Grishyn, B. O., Krazhan, S. A., \& Chuzhma, N. P. (2015). Ocinka rozvytku pryrodnoi' kormovoi' bazy staviv rybnogo gospodarstva "Merkurij" pry vyroshhuvanni ryboposadkovogo materialu koropa. Rybogospodars'ka nauka Ukrai'ny, 4, 34-45. doi: 10.15407/fsu2015.03.034 (in Ukrainian).

Grygorenko, T. V., Kolos, O. M., Savenko, N. M., \& Myhajlenko, N. G. (2016). Vplyv riznyh dobryv na formuvannja gidrohimichnogo rezhymu vyroshhuval'nyh staviv. Rybogospodars'ka nauka Ukrai'ny, 3(37), 22-31. doi: 10.15407/fsu2016.03.022 (in Ukrainian).

Grygorenko, T. V., Postojenko, D. M., Shumygaj, I. V., Dobrjans'ka, O. P., \& Bazajeva, A. M. (2019). Ekologichnyj stan rybnyc'kyh staviv za vyroshhuvannja populjacii' antonins'ko-zozulenec'koi' porody koropa. Agroekologichgyj zhurnal, 4, 65-73. doi: 10.33730/2077-4893.4.2019.189460 (in Ukrainian).

Grynevych, N., Sliusarenko, A., Dyman, T., Sliusarenko, S., Gutyj, B., Kukhtyn, M., Hunchak, V., \& Kushnir,
V. (2018). Etiology and histopathological alterations in some body organs of juvenile rainbow trout Oncorhynchus mykiss (Walbaum, 1792) at nitrite poisoning. Ukrainian Journal of Ecology, 8(1), 402408. doi: 10.15421/2018 228.

Krazhan, S. A., \& Hyzhnjak, M. I. (2014). Pryrodna kormova baza rybogospodar'kyh vodojm: navchal'nyj posibnyk. Kyiv: Agrarna osvita (in Ukrainian).

Pukalo, P. Ja., \& Shekk, P. V. (2018). Parazytarni hvoroby ryb u stavah gospodarstv L'vivs'kogo oblrybkombinatu. Naukovyj visnyk LNUVMB imeni S. Z. G'zhyc'kogo, 20(83), 141-144. doi: 10.15421/nvlvet8327 (in Ukrainian).

Romanenko, V. D. (2006). Metody gidroekologichnyh doslidzhen' poverhnevyh vod. Kyiv: LOGOS (in Ukrainian).

Rudenko, O. P., Paranjak, R. P., Kovalchuk, N. A., Kit, L. P., Hradovych, N. I., Gutyj, B. V., Kalyn, B. M., Sukhorska, O. P., Butsiak, A. A., Kropyvka, S. I., Petruniv, V. V., \& Kovalska, L. M. (2019). Influence of seasonal factors on carp fish immune reactivity. Ukrainian Journal of Ecology, 2019, 9(3), 168-173. URL: https://www.ujecology.com/articles/influence-ofseasonal-factors-on-carp-fish-immune-reactivity.pdf.

Voda rybohospodarskykh pidpryiemstv. Zahalni vymohy ta normy [Water of fishery enterprises. General requirements and standards]. (2006). SOU-05.01.-37385:2006. Kyiv: Ministerstvo ahrarnoi polityky Ukrainy (in Ukrainian).

Vodianitskyi, O., Potrokhov, O., Hrynevych, N., Khomiak, O., Khudiyash, Y., Prysiazhniuk, N., Rud, O., Sliusarenko, A., Zagoruy, L., Gutyj, B., Dushka, V., Maxym, V., Dadak, O., \& Liublin, V. (2020). Effect of reserviour temperature and oxygen conditions on the activity of $\mathrm{Na}-\mathrm{K}$ pump in embrios and larvae of perch, roach, and ruffe. Ukrainian Journal of Ecology, 10(2), 184-189. doi: $10.15421 / 202083$. 